\title{
Effect of salicylic acid foliar application on growth, glandular hairs and essential oil yield in Salvia officinalis L. grown under zinc stress
}

\author{
Fatima Zohra Es-sbihi ${ }^{{ }^{*}}$, Zakaria Hazzoumi ${ }^{2}$ and Khalid Amrani Joutei ${ }^{1}$
}

\begin{abstract}
Background: Generally, zinc ( $(\mathrm{n})$ is an essential element and acts as a plant nutrient, but at higher concentrations, it is toxic. Higher uptake and translocation of $\mathrm{Zn}$ into plant tissues can cause serious physiological and biochemical alterations. However, salicylic acid (SA) is an endogenous regulator of growth and signaling molecule responsible for inducing environmental stress tolerance in plants. Therefore, spray application of SA could provide protection against several types of stresses such as Zn toxicity. In this context, the ameliorative effect of SA ( 0.5 and $1 \mathrm{mM}$ ) on Salvia officinalis L. under Zn stress ( $40 \mathrm{mM}$ ) was studied.

Results: Zn stress decreased growth, chlorophyll content, essential oil yield and peltate glandular trichome density. This toxicity can be linked to a strong accumulation of $\mathrm{Zn}$ in the various parts of the plant. In addition, $\mathrm{Zn}$ stress disturbed nutrients assimilation (K, P and Ca). However, spray of SA, particularly at $0.5 \mathrm{mM}$ improved all parameters studied under both Zn and normal conditions. The positive effects of SA under Zn stress condition may be due to the decrease of $\mathrm{Zn}$ accumulation in different parts of the plant. This decrease was accompanied by an increase in $\mathrm{K}, \mathrm{P}$ and Ca content. In addition, the histological study of $S$. officinalis leaves showed the presence of two types of glandular hairs, the peltate and capitate glands. In the leaves of stressed plants, we noticed the presence of glands with deformations in the form of pockets in the number of one or more as well as the glands with an oval form. On the other hand, all these abnormalities glands were not detected in stressed plants that were sprayed with SA. Therefore, the absence of these anomalies under the effect of SA showed the remedial effect of this growth regulator.
\end{abstract}

Conclusion: The findings of the present work suggest that spraying SA maybe useful for improving the plant growth in Zn-contaminated areas.

Keywords: Salvia officinalis, Zinc, Stress, Salicylic acid, Glandular hairs

\section{Background}

The essential oil of S. officinalis presented high industrial and medicinal application. According to a previous study of Es-sbihi et al. [1] and Hazzoumi et al. [6], the main components of $S$. officinalis essential oils was cis-thujone, trans-thujone, camphor, 1,8-cineole. In the fruits of S. officinalis, Taarit et al. [2] showed that viridiflorol,

\footnotetext{
*Correspondence: essbihi.fatimazohra@gmail.com

${ }^{1}$ Microbial Biotechnology and Bioactive Molecules Laboratory: Faculty

of Science and Technology Fez, Sidi Mohamed Ben Abdellah University, B.P. 2202-Road of Imouzzer, Fez, Morocco

Full list of author information is available at the end of the article
}

1,8-cineole, thujone, camphor, borneol, caryophyllene, manool, thujone, pinene, linalool and caryophyllene oxide were the main compounds. The accumulation of essential oil is limited to specialized secretory structures, namely, glandular trichomes. Özkan [3], Werker et al. [4], Bisio et al. [5] and Hazzoumi et al. [6] subdivided these glands into peltate hairs and capitate hairs, based on morphological criteria, the secretory material, the mode and the moment of secretion.

However, the metallic elements nature and their concentrations in the soil have a strong impact on plant growth. Depending on their concentrations, 
these elements can play the benefic or toxic role. The toxicity is manifested by growth inhibition [7], nutritional imbalance [8] as well as by inactivation of biomolecules by blocking functional groups or by exchange of vital ions [9]. It can also lead to variations in the yield and composition of essential oil [9-11]. Chaney [12] and Marschner [13] reported that symptoms of zinc toxicity become visible at concentrations above $300 \mathrm{mg} \mathrm{kg} \mathrm{kg}^{-1}$ dry matter (DM), although some cultures exhibit symptoms of toxicity at concentrations below $100 \mathrm{mg} \mathrm{kg}{ }^{-1}$ DM. Macfarlane and Burchett [14] showed that $\mathrm{Zn}$ at $125 \mu \mathrm{g} \mathrm{g}^{-1}$ in soil stimulated the growth parameters of Avicennia marina while it becomes toxic from $500 \mu \mathrm{g} \mathrm{g}^{-1}$ in soil. On certain aromatic and medicinal plants, Macnicol and Beckett [15] have shown that doses of $\mathrm{Zn}$ between 200 and $400 \mu \mathrm{g} \mathrm{g}^{-1}$ of soil had a harmful effect. Thus, Misra [8] showed a decrease in the menthol contents when the $\mathrm{Zn}$ concentration increased in the mint leaves. Exogenous applications of growth regulators have been shown to be effective in improving plant growth and yield production under $\mathrm{Zn}$ stress. Among these regulators, $\mathrm{SA}$ is an endogenous growth regulator [16] naturally found in plants in very small quantities. It is considered as a chemical messenger that plays an important role in biotic and abiotic stress tolerance. SA plays a role in the regulation of various physiological processes [17-19]. It also plays a role in seeds germination [20], fruit yield, glycolysis, flowering in thermogenic plants [21], ion capture and transport [22]. Under abiotic stress conditions, the remedial effect of SA on growth is linked to its role on the physiological parameters of the plant such as water content, nutrients assimilation, chlorophyll pigments biosynthesis, growth, regulation stomatal, inhibition of ethylene biosynthesis, regulation of hormonal profile and synthesis of protein kinase [23-26]. Our previous works [1] have shown the positive effect of SA on growth and on the accumulation of certain minerals $(\mathrm{Ca}, \mathrm{K}$ and $\mathrm{P})$ in $\mathrm{S}$. officinalis grown under copper stress. Additionally, several studies showed that exogenous SA contributes to the regulation of the metabolic and physiological pathways of plants grown under heavy metals such as copper, cadmium, chromium and lead on plants [27-31]. On the other hand, the effect of SA on the toxicity of Zn was not studied. It is therefore relevant to examine the influence of SA on the regulation of various physiological and biochemical activities of $S$. officinalis L. grown under Zn stress.

In this context, we investigated the influence of SA on the toxic effects of $\mathrm{Zn}$ stress on S. officinalis L. on plant growth, mineral uptake, essential oil yield and secretory glands.

\section{Materials and methods \\ Plant material and growth conditions}

Salvia officinalis L. cuttings were taken from the botanical garden of the Faculty of Science and Technology, Fez. Each cutting included at least two nodes. Culturing was carried out in plastic pots (3 kg capacity) containing 5 plants per pot and grown in a greenhouse.

\section{$\mathrm{Zn}$ and SA treatments}

After 30 days of plants transplantation (DAT), they were watered with $40 \mathrm{mM}$ solution of $\mathrm{ZnSO}_{4}$. This $\mathrm{Zn}$ dose was chosen because a preliminary experiment showed that from $40 \mathrm{mM} \mathrm{Zn}$ induced growth inhibition of S. officinalis. Zn was applied weekly over a 5-week period ( $200 \mathrm{ml}$ per pot). SA (0.5 and $1 \mathrm{mM})$ was applied by foliar spray at 60 DAT (these SA concentrations were chosen based on a preliminary screening experience). Three SA sprays were performed at a weekly interval using a hand sprayer (100 $\mathrm{ml}$ per pot).

This experiment includes total six treatments: control, $0.5 \mathrm{mM}$ salicylic acid (SA $0.5 \mathrm{mM}), 1 \mathrm{mM}$ salicylic acid (SA $1 \mathrm{mM}), 40 \mathrm{mM} \mathrm{ZnSO} 4(\mathrm{Zn}), 40 \mathrm{mM}$ $\mathrm{ZnSO} 4+0.5 \mathrm{mM}$ salicylic acid $(\mathrm{Zn}+\mathrm{SA} 0.5 \mathrm{mM})$ and $40 \mathrm{mM} \mathrm{ZnSO} 4+1 \mathrm{mM}$ salicylic acid (Zn+SA $1 \mathrm{mM})$. The experiment was performed in five replicates and sampling was done at 100 DAT.

\section{Dosage of chlorophyll total}

Fragments of leaves $(1 \mathrm{~g})$ were ground in a mortar previously placed in ice with a pinch of magnesium carbonate and $5 \mathrm{~g}$ of anhydrous sodium sulfate. Then, $10 \mathrm{ml}$ of $80 \%$ acetone was poured into the ground material, which was filtered on a Buchner, the residue was recovered in essays tubes. Further extractions were carried out with acetone to obtain a colorless filtrate (devoid of all traces of chlorophyll pigments) for which the final volume was specified. OD measurements were made with a spectrophotometer at wavelengths of around $663 \mathrm{~nm}$ to $645 \mathrm{~nm}$ for chlorophyll (a) and chlorophyll (b).

McKinney [32] established systems of equations that calculate the concentrations $\left(\mathrm{g} \mathrm{l}^{-1}\right.$ ) chlorophyll from absorbance at 663 and $645 \mathrm{~nm}$ of an extract of $80 \%$ acetone are:

1. Chlorophyll $\mathrm{a}=(0.0127$ OD663 $)-(0.00269$ OD 645),

2. Chlorophyll $\mathrm{b}=(0.0229$ OD 645$)-\left(\begin{array}{lll}663 & 0.00468\end{array}\right.$ OD), 
3. Total chlorophyll $=(0.0202$ OD 645$)+(0.00802$ OD 663).

\section{$\mathrm{Zn}$ and nutrients $(\mathrm{K}, \mathrm{P}$ and $\mathrm{Ca})$ content}

Content of $\mathrm{Zn}$ and minerals ( $\mathrm{K}, \mathrm{P}$ and $\mathrm{Ca}$ ) was determined according to Cottenie et al. [33]. The root and shoot samples of $S$. officinalis were dried at $100{ }^{\circ} \mathrm{C}$ for $48 \mathrm{~h} .100 \mathrm{mg}$ of dried plant was calcined at $450{ }^{\circ} \mathrm{C}$ for $12 \mathrm{~h}$ in a muffle furnace. The ash obtained was dissolved in $3 \mathrm{ml}$ of nitric acid $(0.1 \mathrm{~N})$ and then filtered through Whatman filter paper 540 hardened ashless. The volume was adjusted to $20 \mathrm{ml}$ with distilled water. Based on this solution, the assay was performed by inductively coupled plasma emission spectrometry (ICP-AES) to determine the content of $\mathrm{Zn}$ and minerals (K, P and $\mathrm{Ca}$ ).

\section{Environmental scanning electron microscope}

Microscopic observations of the fresh leaves were made using an environmental scanning electron microscope (Quanta 200, FEI Company). The microscope was equipped with a tungsten electron gun. Analyses were carried out under partial pressure of water vapor.

\section{Count of peltate glandular trichome}

Peltate glands counting was performed on the ventral side of the fresh leaves on a $1 \mathrm{~mm}^{2}$ area, taking into consideration the basal (near the petiole), central and apical areas of the leaf. For each treatment, the glands number represents the average of glands of five plants and three leaves per plant [34].

\section{Essential oil extraction}

Essential oil extraction was carried out by hydrodistillation (Clevenger apparatus) of $100 \mathrm{~g}$ of parts aerial of $S$. officinalis dried in the free area. The extraction was carried out in $2 \mathrm{~L}$ of distilled water for $180 \mathrm{~min}$. The essential oil was collected, dehydrated with sodium sulfate and stored at $4{ }^{\circ} \mathrm{C}$. Essential oil yield was calculated by the following formula [35]:

$$
\mathrm{YEO}(\mathrm{ml} / 100 \mathrm{~g} \mathrm{DM})=(V / \mathrm{DM} \times 100) .
$$

YEO is the essential oil yield of DM, V is the volume of essential oil collected ( $\mathrm{ml})$, and DM is the dry plant weight $(\mathrm{g})$.

\section{Statistical analysis}

One-way analysis of variance was carried out for each parameter studied. Tukey's post hoc multiple mean comparison test was used to test for significant differences between treatments $(P \leq 0.05)$. Univariate analysis was used to test significant differences in treatments, accessions, and their interaction for an individual parameter. All statistical analyses were performed with IBM. SPSS statistics, Version 22. The results of each experiment (biochemical assays) were repeated three times (20 times for morphological assays).

\section{Results}

Plant growth

In the case of non-stress, the plants sprayed with SA at $0.5 \mathrm{mM}$ showed an increase of the growth by $44 \%$ and $56 \%$ of the stem and root parts, respectively, compared to the control (Fig. 1). At a higher concentration (1 mM), no significant differences were observed. In addition, in the absence of SA, Zn reduced stem and root growth, since a decrease in length can be observed which can reach $44 \%$.

However, spraying of SA on the stressed plants increased the length of the aerial and root at the two concentrations 1 and $0.5 \mathrm{mM}$. Moreover, $0.5 \mathrm{mM}$ presents the most pronounced results with an increase which can reach $50 \%$ for the aerial part.

\section{Total chlorophyll content}

In non-stress condition, $\mathrm{SA}$ at $0.5 \mathrm{mM}$ increased the chlorophyll content in S. officinalis with 79\% (Fig. 2). Zn stress significantly reduced total chlorophyll content (with 52\% compared to the control). However, foliar spraying of SA, particularly at $0.5 \mathrm{mM}$ improved chlorophyll synthesis, this increase was estimated by $501 \%$ compared to stressed plants untreated with SA.

\section{$\mathrm{Zn}$ accumulation and mineral elements in plant}

Table 1 shows the accumulation of $\mathrm{Zn}, \mathrm{Ca}, \mathrm{K}$ and $\mathrm{P}$ according to the different culture conditions. In nonstress conditions, the SA generally increased mineral element $(\mathrm{Ca}, \mathrm{K}$ and $\mathrm{P}$ ) contents compared to the control. At the leaf, whatever the concentration of SA used, there was a slight increase in the Ca contents, but a significant accumulation of $\mathrm{K}$ and $\mathrm{Zn}$. In non-stress conditions, the SA generally increased mineral elements contents compared to the control. Under stress conditions, $\mathrm{Zn}$ was accumulated significantly at the roots (compared to the control) and can even be translocated to the leaves where its contents reach high values $\left(3.31 \mathrm{mg} \mathrm{g}^{-1} \mathrm{MS}\right.$ against $0.48 \mathrm{mg} \mathrm{g}^{-1} \mathrm{MS}$ for the control). This accumulation of $\mathrm{Zn}$ in the plant was accompanied by a decrease in the $\mathrm{Ca}, \mathrm{K}$ and $\mathrm{P}$ contents. Spraying SA significantly decreased $\mathrm{Zn}$ accumulation in roots and its translocation to shoots. These decreases were more pronounced at $0.5 \mathrm{mM}$ with $74 \%$ and $87 \%$, respectively, in the leaves and roots compared to stressed plants untreated with SA. This concentration of SA $(0.5 \mathrm{mM})$ promotes the increased absorption of mineral elements in both parts of 
the plant (leaves and roots), which can reach $58 \%$ for $\mathrm{Ca}$, $198 \%$ for K, $131 \%$ for P at the leaf level, and $44.54 \%$ for $\mathrm{Ca}, 303 \%$ for $\mathrm{K}$ and $59 \%$ for $\mathrm{P}$ at the root level, compared to stressed plants not treated with SA.

\section{Essential oil yield}

In non-stressed plants, SA is involved in essential oil synthesis (Table 2). This increase in essential oil contents was proportional to the concentration of SA; it can reach 25\% for the SA at $0.5 \mathrm{mM}$ and $50 \%$ for SA at $1 \mathrm{mM}$ compared to control. On the other hand, $\mathrm{Zn}$ stress significantly decrease essential oil synthesis, which pass from $1.2 \%$ to $0.4 \%$ (reduction of $67 \%$ compared to control). Nevertheless, foliar spraying of SA on stressed remedy the negative effect of $\mathrm{Zn}$ by increasing the essential oil yield. This increase was estimated by $425 \%$ at $0.5 \mathrm{mM}$ and by $250 \%$ at $1 \mathrm{mM}$ compared to stressed plants not treated with SA.

\section{Peltate glandular trichome density}

Microscopic observations made on the leaves of S. officinalis, showed a difference in peltate glands abundance along the leaf, since they were concentrated at the basal part more than the central and apical part, this gradient (basal >central >apical) remains the same whatever the treatment. Moreover, the number of glands varies according to the treatment applied (Zn, SA) (Figs. 3 and 4). $\mathrm{Zn}$ stress decreased peltate glands density (Fig. $4 \mathrm{~b}$ ) in the different areas of the leaf (Fig. 3). Compared to the control (Fig. 4a), this decrease estimated by $40 \%$ at the basal, $38 \%$ central levels and $47 \%$ at the apical level (Fig. 3). On the other hand, spray of SA increased the density of the glands in the different zones of the leaf (Fig. 3). This increase was more pronounced at $0.5 \mathrm{mM}$ (Fig. 4c) and can reach $177 \%$ in the basal area, $215 \%$ in the central area and 222\% in the apical area (Fig. 3) compared to stressed plants untreated with SA.

\section{Histological study of glandular trichomes}

Microscopic observations in control plants showed the existence of the protective hairs (non-glandular hairs) and two types of secretory glands: peltate and capitate (Fig. 5a). The peltate and capitate glands differ in the size of the head, the length of the stem, mode and the period of secretions. The peltate glands are formed by a basal cell, a short, unicellular stem and head wide and round. The capitate glands consist of a base including epidermal cells, a longer (multicellular) stem and a smaller head than that of the capitate glands.

In addition to these common forms of the glands, the treatment with $\mathrm{Zn}$ revealed structures characterized by atypical morphology, presenting deformations in the
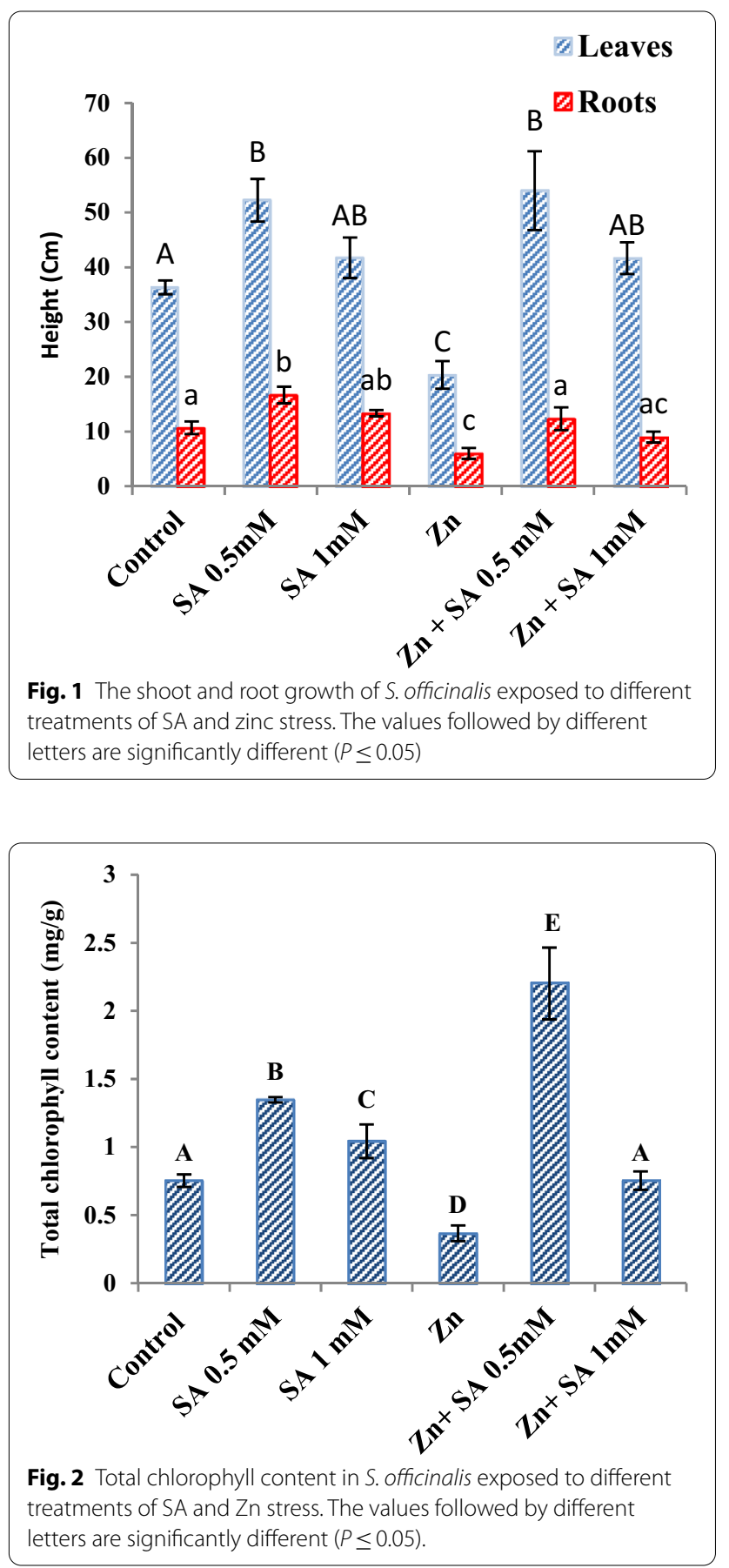

form of pockets on their surface (Figs. 5b and 6). These pockets, generally spherical, can be either unique or numerous on the same gland. In addition, another form of deformation may appear, it was the oval form (Fig. 7) instead of the usually spherical shape of the glands.

In addition, in plants treated with SA $(0.5$ and $1 \mathrm{mM})$ these deformed structures were not detected, which does encourage us to suggest that the toxicity of $\mathrm{Zn}$ caused 
Table 1 Content of $\mathrm{Zn}$ and mineral nutrients ( $\mathrm{P}, \mathrm{K}$ and $\mathrm{Ca}$ ) in S. officinalis exposed to different treatments of SA and $\mathrm{Zn}$ stress

\begin{tabular}{|c|c|c|c|c|}
\hline & Zn (mglg DM) & Ca (mglg DM) & K (mglg DM) & P (mglg DM) \\
\hline \multicolumn{5}{|l|}{ Leaves } \\
\hline Control & $0.48 \pm 0.03 \mathrm{~A}$ & $12.56 \pm 0.09 a$ & $11.41 \pm 0.94 \mathrm{~A}^{*}$ & $2.47 \pm 0.11 a^{*}$ \\
\hline $\mathrm{SA}(0.5 \mathrm{mM})$ & $0.83 \pm 0.07 \mathrm{~B}$ & $13.86 \pm 0.02 b$ & $19.27 \pm 1.10 B^{*}$ & $2.66 \pm 0.05 a^{*}$ \\
\hline $\mathrm{SA}(1 \mathrm{mM})$ & $0.92 \pm 0.01 C$ & $13.19 \pm 0.41 b$ & $15.03 \pm 0.37 C^{*}$ & $2.47 \pm 0.11 a^{*}$ \\
\hline $\mathrm{Zn}$ & $3.31 \pm 0.18 \mathrm{D}$ & $9.74 \pm 0.36 c$ & $9.41 \pm 0.21 D^{*}$ & $0.72 \pm 0.10 b^{*}$ \\
\hline $\mathrm{Zn}+\mathrm{SA}(0.5 \mathrm{mM})$ & $0.87 \pm 0.01 \mathrm{~B}$ & $15.37 \pm 0.12 d$ & $28.07 \pm 0.29 \mathrm{E}^{*}$ & $1.67 \pm 0.11 c^{*}$ \\
\hline $\mathrm{Zn}+\mathrm{SA}(1 \mathrm{mM})$ & $1.06 \pm 0.05 \mathrm{E}$ & $12.55 \pm 0.21 \mathrm{a}$ & $26.62 \pm 0.17 \mathrm{~F}^{*}$ & $1.68 \pm 0.21 c^{*}$ \\
\hline \multicolumn{5}{|l|}{ Roots } \\
\hline Control & $0.50 \pm 0.01 a$ & $8.41 \pm 0.07 \mathrm{~A}$ & $6.42 \pm 0.05 a^{*}$ & $1.01 \pm 0.01 \mathrm{~A}^{*}$ \\
\hline $\mathrm{SA}(0.5 \mathrm{mM})$ & $0.51 \pm 0.00 a$ & $16.11 \pm 0.10 \mathrm{~B}$ & $12.84 \pm 0.02 b^{*}$ & $3.85 \pm 0.01 B^{*}$ \\
\hline $\mathrm{SA}(1 \mathrm{mM})$ & $0.90 \pm 0.08 b$ & $15.03 \pm 0.37 C$ & $8.87 \pm 0.02 c^{*}$ & $1.13 \pm 0.01 A^{*}$ \\
\hline $\mathrm{Zn}$ & $6.89 \pm 0.66 c$ & $6.87 \pm 0.19 D$ & $4.05 \pm 0.04 d^{*}$ & $0.54 \pm 0.12 C^{*}$ \\
\hline $\mathrm{Zn}+\mathrm{SA}(0.5 \mathrm{mM})$ & $0.89 \pm 0.00 \mathrm{~b}$ & $9.93 \pm 0.11 \mathrm{E}$ & $16.33 \pm 0.29 e^{*}$ & $0.86 \pm 0.12 D^{*}$ \\
\hline $\mathrm{Zn}+\mathrm{SA}(1 \mathrm{mM})$ & $1.16 \pm 0.00 d$ & $8.78 \pm 0.02 \mathrm{~F}$ & $18.26 \pm 0.11 f^{*}$ & $0.69 \pm 0.10 D^{*}$ \\
\hline
\end{tabular}

The values within vertical lines followed by different letters are significantly different $(P \leq 0.05)$

Table 2 Yield of essential oil (\%) in S. officinalis exposed to different treatments of SA and Zn stress

\begin{tabular}{llllll}
\hline Control & SA & SA $1 \mathrm{mM}$ & $\mathrm{Zn}$ & $\mathrm{Zn}+\mathrm{SA}$ & $\mathrm{Zn}+\mathrm{SA}$ \\
& $0.5 \mathrm{mM}$ & & & $0.5 \mathrm{mM}$ & $1 \mathrm{mM}$
\end{tabular}

$1.2 \pm 0.01 a \quad 1.5 \pm 0.05$ b $1.8 \pm 0.01 c \quad 0.4 \pm 0.1 d \quad 2.1 \pm 0.02$ e $1.4 \pm 0.01 \mathrm{f}$

The values followed by different letters are significantly different $(P \leq 0.05)$

this structural anomaly, and SA treatment corrects the negative effects of $\mathrm{Zn}$ stress.

\section{Discussion}

The present study indicated that $\mathrm{Zn}$ stress inhibits stem and root growth of $S$. officinalis, which is in agreement with previous works $[7,36]$. In addition, Sagardoy et al. [37] reported in Beta vulgaris L. that increasing Zn concentrations leads to a decrease in the dry weight, with the appearance of chlorosis symptoms. Furthermore, applying $40 \mathrm{mM} \mathrm{Zn}$ to the growth media significantly elevated the $\mathrm{Zn}$ concentrations in various parts of sage plants with a maximum accumulation in the roots. Macfarlane and Burchett [14], Frey et al. [38] reported that $\mathrm{Zn}$ accumulated in the vacuoles of epidermis cells and leaf mesophylls. In addition, Turner and Marshall [39] indicated that the exclusion of metals in the roots maybe a mechanism of tolerance since metals bind to the cell walls of the roots and the extent of this bond is proportional to the degree of tolerance to heavy metal. Some authors reported that symptoms of toxicity become visible at concentrations above $300 \mathrm{mg} \mathrm{kg}^{-1}$ of DM, although some cultures exhibit symptoms of toxicity at concentrations below $100 \mathrm{mg} \mathrm{kg}^{-1} \mathrm{DM}[12$, 13]. These high concentrations caused a nutritional imbalance, which results in growth retardation $[8,40]$. Other researchers reported the same effect after accumulation of other metals such as copper [1, 41, 42] and cadmium $[3,43]$. In this perspective, our results showed that the mineral content in root and shoot was also significantly decreased by $\mathrm{Zn}$ stress. These results are confirmed by Sagardoy et al. [37] who showed that increasing of $\mathrm{Zn}$ concentrations decreases the concentrations of several nutrients in Beta vulgaris L. such as $\mathrm{K}, \mathrm{Mg}, \mathrm{Mn}, \mathrm{P}, \mathrm{Ca}$ and Fe. In addition, Ambler et al. [44] reported an inhibition of iron translocation from the root to the leaves which caused chlorosis. Furthermore, the essential oil production was strongly inhibited by $\mathrm{Zn}$ stress confirming the results of Misra and Sharma [9] and Misra et al. [8] who showed disturbances in essential oil contents in Mentha arvensis at higher $\mathrm{Zn}$ concentrations (at $25 \mu \mathrm{g} \mathrm{g}^{-1} \mathrm{DM}$ ). Copetta et al. [34] and Hashmi et al. [45] demonstrated the importance of mineral nutrition on essential oil yield. In this sense, we can link this negative effect of $\mathrm{Zn}$ on essential oil to the nutritional imbalance under $\mathrm{Zn}$ toxicity. In addition, the $\mathrm{Zn}$ stress application impact negatively the chlorophyll levels. The biosynthesis of essential oil as a secondary metabolite was linked to photosynthetic activity [46] and that metals caused disturbances of chlorophylls synthesis, following the synthesis of free radicals $[8,47]$. In this study, it has been found that essential oil of S. officinalis L. was strongly correlated with secretory glands density. Same observation was made by others authors $[46,48]$. 


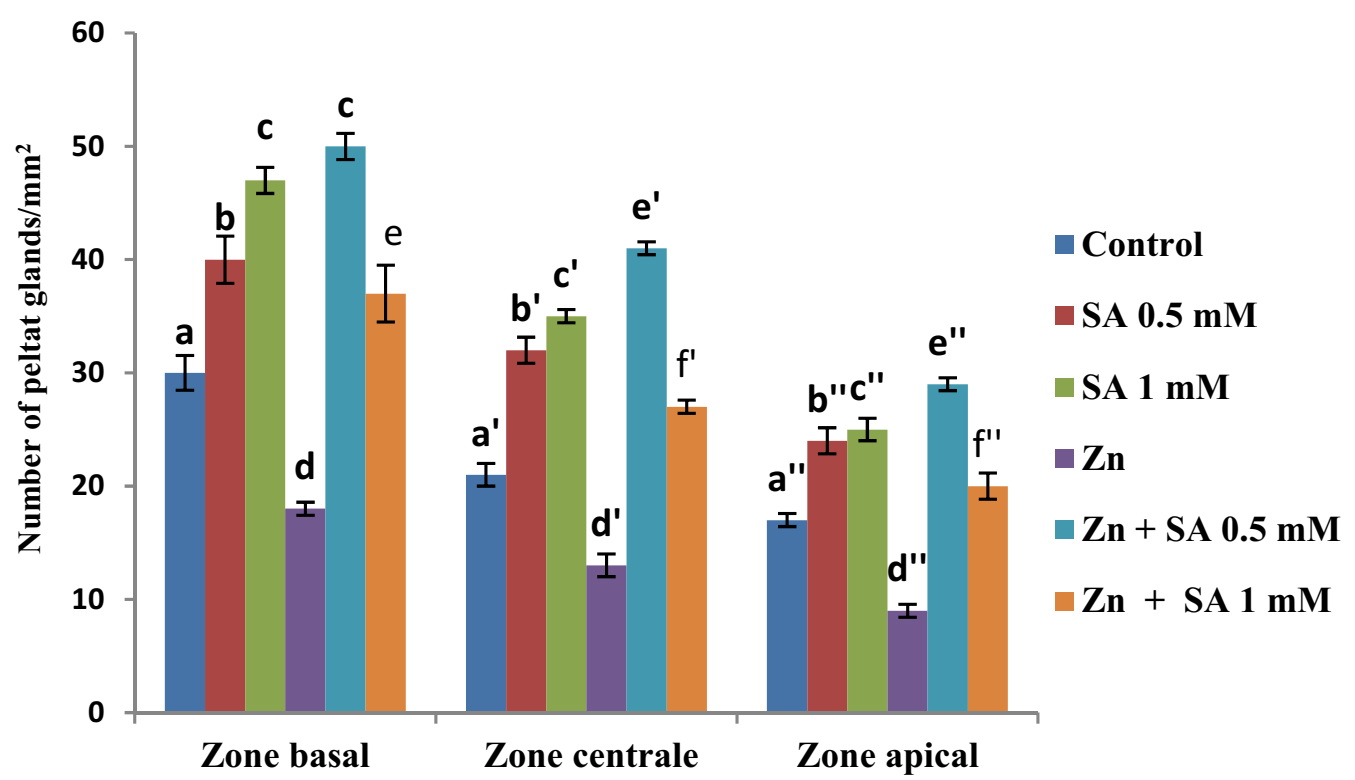

Fig. 3 Peltate glands abundance on the adaxial surface of S. officinalis leaves exposed to different treatments of SA and Zn stress. The values followed by different letters are significantly different $(P \leq 0.05)$

The observations made by environmental scanning electron microscopy of $S$. officinalis leaves showed the presence of peltate, capitate glands and non-glandular trichomes (protective hairs). Hazzoumi et al. [6] noted in S. officinalis also the presence of peltate glands with a unicellular stem and a large round head, and of capitate glands with a longer stem and a smaller head than that in peltate glands. These same structures have also been encountered in the leaves of plants grown under $\mathrm{Zn}$ stress. However, in these stressed plants, we highlighted the presence of some anomalies never observed in the control plants and in plants treated with SA. These anomalies consist of glandular structures with deformations in the form of pockets located on the head. The number of these pockets can be variable (in number of 1 or more).

These pockets can be either a drop of secretion or abnormalities caused by $\mathrm{Zn}$ toxicity. The latter hypothesis seems to be as possible as these structures only appear in plants treated with $\mathrm{Zn}$. Indeed, we have never been able to meet such structures in control plants and in plants sprayed with SA. In this sense, the hypothesis of an excretion oil was excluded because:

The peltate glands release their contents to outside by bursting of the cuticle. Chez genus Salvia, Corsi and Bottega [49]; Serrato-Valenti et al. [50]; Bisio et al. [5] and Janošević et al. [51] stated that at the time of secretion, a large space in which materials accumulate has developed through the elevation of the cuticle and the outermost layer of the walls of the secretory cells.
A line of equatorial weakness became visible around the head; the rupture of the cuticle along this line and the subsequent detachment of the cuticular cap lead to the release of exudate. These same authors showed that matter is not released until the cuticle is broken by mechanical events or at the end of the gland's life.

The capitate glands release their contents through a single pore. But, in our case on the same glands several pockets were observed (in number of 1 or more). In this sense, Bisio et al. [5] reported in the genus Salvia two potential mechanisms for the release of secreted material for the capitate glands: (1) the passage of a droplet through the intact cuticle; or (2) early cuticle (single pore) rupture.

In addition, our observations showed also in stress case, the presence of the glands characterized by an oval morphology which were not encountered in the control and in the plants treated with SA. Therefore, it can be deduced that all these glandular structures observed can be considered as anomalies caused by the $\mathrm{Zn}$ toxicity. Several authors have used exogenous SA against certain biotic stresses $[52,53]$ and abiotic such as saline stress $[54,55]$, water stress [56]; heat stress [57], cadmic stress [58]. On the other hand, on the toxicity of $\mathrm{Zn}$, the effect of SA was not studied. On Zn toxicity, this work showed the positive effect of SA, particularly at $0.5 \mathrm{mM}$, on the stem and root growth. The stimulation of growth by SA can be linked to the mineral nutrition, the hormonal profile, and photosynthesis. Several authors linked the positive effect of SA on growth to its positive effect on 

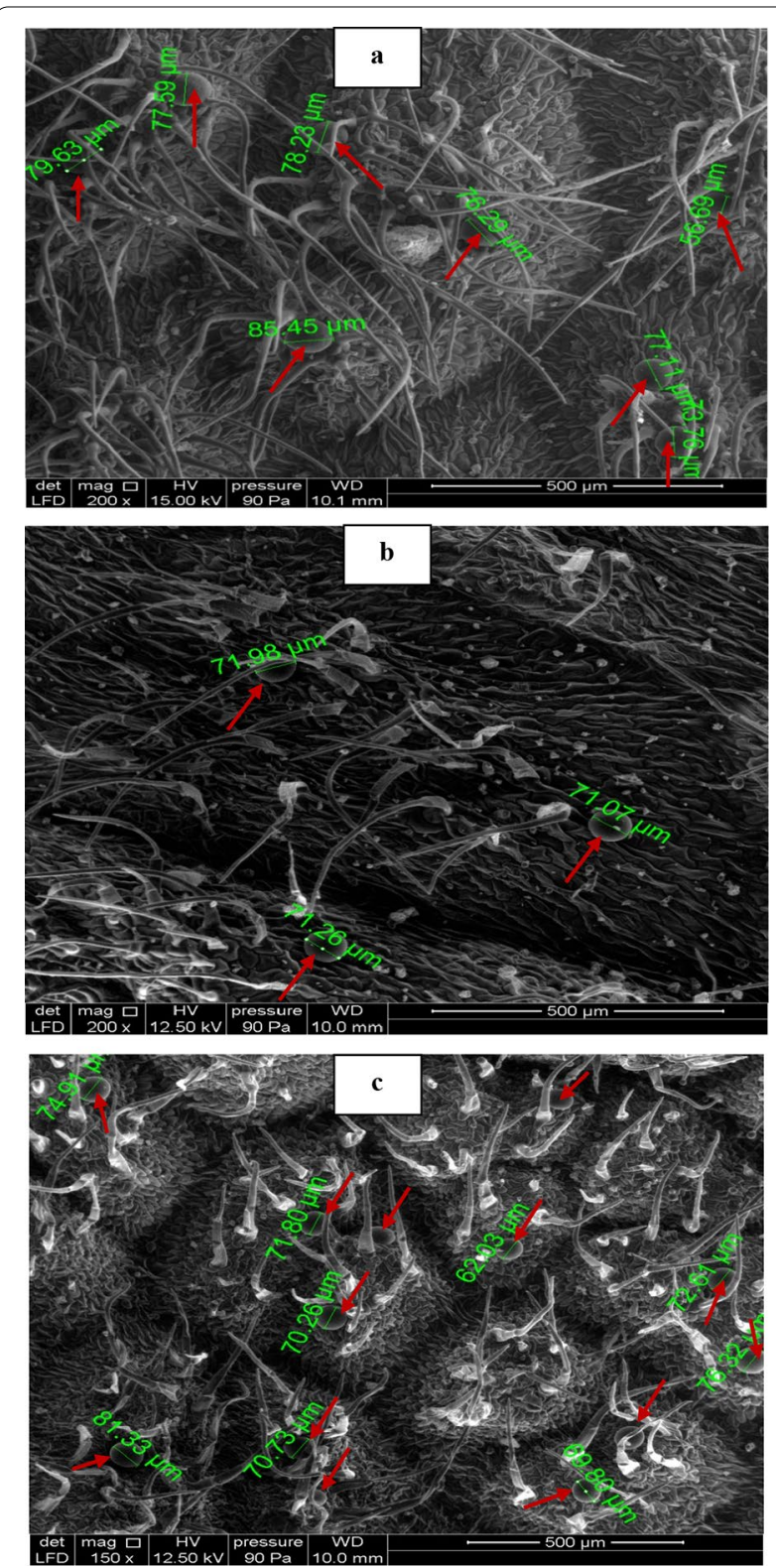

Fig. 4 Observation by environmental scanning electron microscopy of S. officinalis: control (a); $\mathrm{Zn}(\mathbf{b}) ; \mathrm{Zn}+\mathrm{SA} 0.5 \mathrm{mM}$ (c)

hormonal balance disturbed by metallic stress. Shakirova et al. [59] showed in wheat treated with SA increased ABA content, which plays a role in regulating the movements of the stomata [60], in the regulation of genes and the activity of antioxidant enzymes [61]. Shakirova et al. [62] concluded that endogenous $\mathrm{ABA}$ is a hormonal intermediary to trigger defense reactions under the influence of SA. These results are confirmed by the results of Guo et al. [63] on cadmium, and de Gunes et al. [64] on copper. In addition, we showed the positive effect of SA on the synthesis of chlorophyll pigments confirming
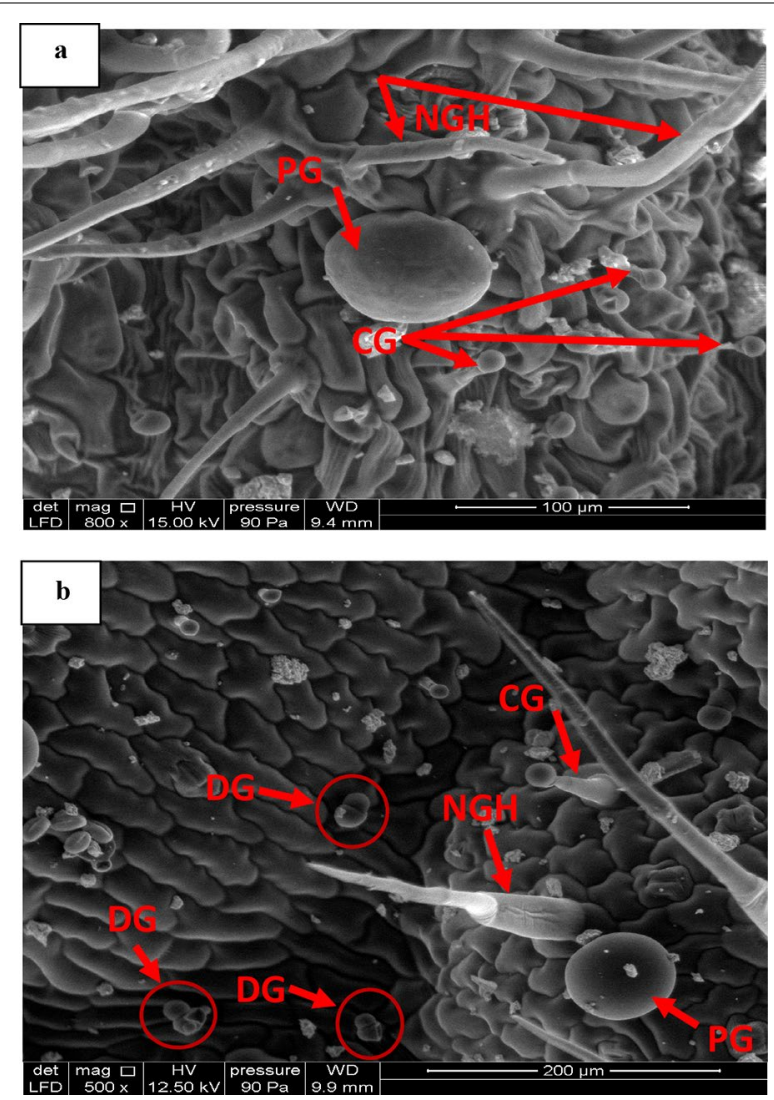

Fig. 5 Observation by environmental scanning electron microscopy of the adaxial of $S$. officinalis leaves from control (a) and plants treated with Zn (b). PG peltate gland, NGH non-glandular hairs, CG capitate glands, $D G$ deformed gland

the results of Tahjib et al. [65] in corn and Faghih et al. [66] in strawberry plant under saline stress. The improvement of photosynthesis under the influence of SA can be attributed to its stimulating effects on the activity of RuBisCO, PEP carboxylase and carbonic anhydrase [67]. Others attributed the positive effect of SA on chlorophyll content to the stimulation of mineral assimilation and to the effectiveness of PSII [68], to the mobilization of internal tissue nitrate or to the chlorophyll biosynthesis [69]. Spraying of SA, particularly at $0.5 \mathrm{mM}$, increased the essential oil content in stressed plants. In stress condition, Khanam and Mohammad [70] on Mentha piperita L. and Es-sbihi et al. [1] on S. officinalis L. showed also an increase in essential oil content under the effect of SA. These authors linked this increased in essential oil content under SA in stress condition, to the improvement of growth, photosynthesis, nutrient assimilation and peltate glands density. Others also demonstrated also that spraying of SA increased peltate glands density [71, 72]. In this sense, this study showed an increase in peltate glands density in S. officinalis grown under Zn stress and 

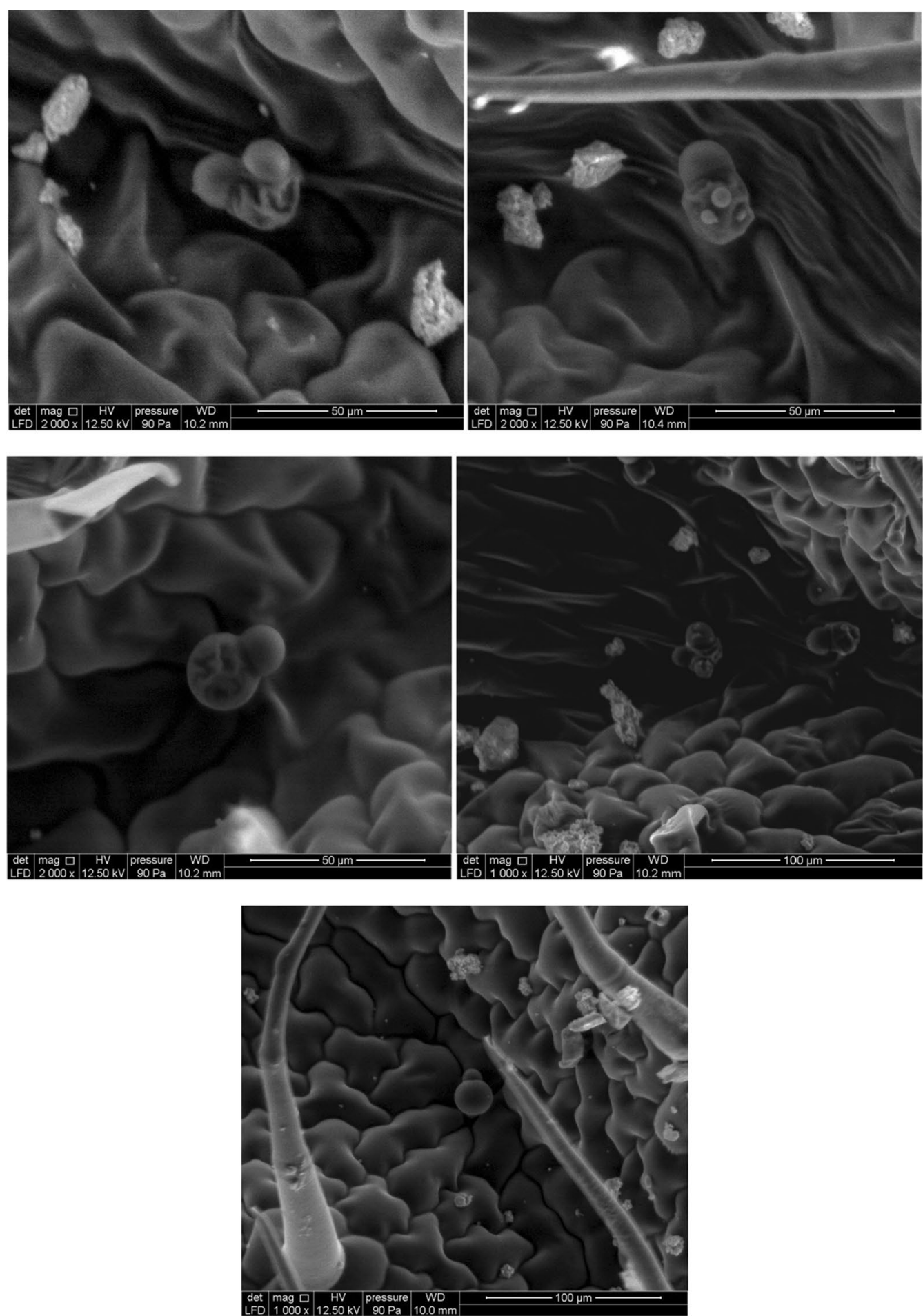

Fig. 6 Observation by environmental scanning electron microscopy of the adaxial of S. officinalis leaves shows deformed glands under the effect of zinc

sprayed with SA (especially at $0.5 \mathrm{Mm}$ ). Some authors attributed this positive effect of SA to improvement of the hormonal profile [34, 35] like auxins and gibberellins $[45,73]$. In Zea mays exposed to cadmic stress, Szalai et al. [58] found that the application of SA at $0.5 \mathrm{mM}$ increased the levels of phytochelatins, responsible for the tolerance of plants to metal ions. In our study, this positive effect of SA on growth, chlorophyll and essential oil 

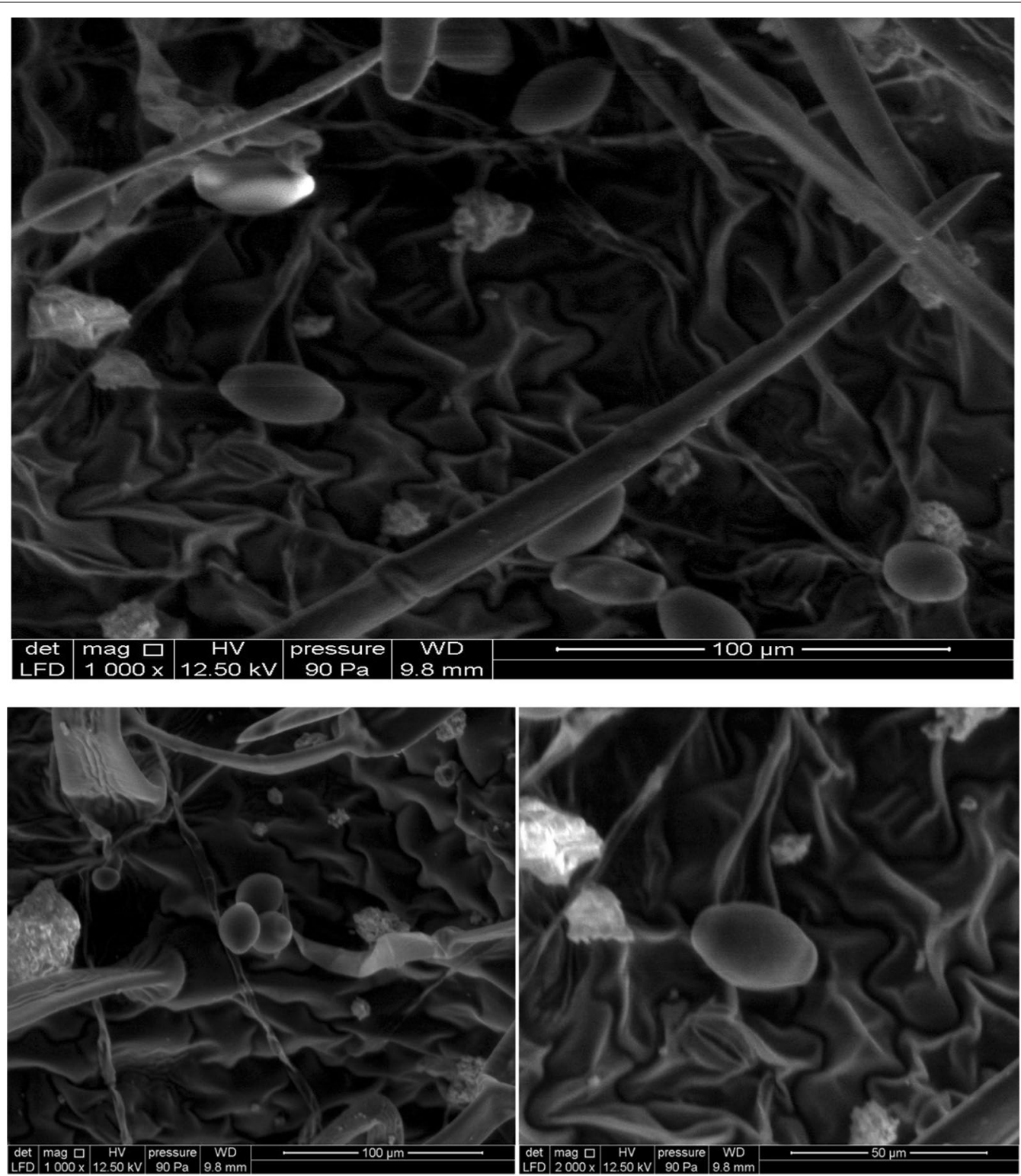

Fig. 7 Observation by environmental scanning electron microscopy of the adaxial of S. officinalis leaves from plants treated with Zn

biosynthesis under $\mathrm{Zn}$ stress could be related with limiting $\mathrm{Zn}$ uptake and translocation in leaves under stressful environment and to the improvement of the nutritional balance disturbed by $\mathrm{Zn}$ accumulation.

However, histological study of the leaves of stressed plants sprayed with SA showed the presence of similar peltate and capitate glands observed in the control. On the other hand, in these plants we never detected the structures discovered in stressed plants untreated with $\mathrm{SA}$. This finding confirms the hypothesis which stipulates that these deformations are anomalies that appear under the effect of toxic concentrations of $\mathrm{Zn}$. Spraying SA decreased $\mathrm{Zn}$ uptake which explains the disappearance of these structures discovered in stressed plants.

\section{Conclusion}

Zn stress inhibited growth and the synthesis of chlorophyll and essential oil. However, spraying of SA (particularly at $0.5 \mathrm{mM}$ ) reduced $\mathrm{Zn}$ content and promoting nutrients content, growth, chlorophyll, essential oil and peltate glandular in S. officinalis grown under $\mathrm{Zn}$ stress. 
The histological study of the leaves of plants cultivated under $\mathrm{Zn}$ stress showed the presence of the glands with deformations in the form of pockets located on the surface of the head and glands characterized by an oval morphology not detected in plant control. However, sprayed with SA $(0.5$ and $1 \mathrm{mM})$ we noticed the absence of these glandular anomalies which showed the remedial effect of SA under Zn stress.

\section{Abbreviations}

SA: Salicylic acid; Zn: Zinc; DM: Dry matter; DAT: Days of plants transplantation.

\section{Acknowledgements}

Not applicable

\section{Authors' contributions}

All authors of this research paper have directly participated in planning, execution and analysis of the study. All authors read and approved the final manuscript.

\section{Funding}

The authors have not received any funding.

\section{Availability of data and materials}

Additional data may be availed on request to the authors through the corresponding author. We take legal responsibility for information, used procedures, data and results.

\section{Ethics approval and consent to participate}

This research work meets all the ethical guidelines, adhering to the legal requirements of my country.

\section{Consent for publication}

The authors confirm that there is no conflict of interest and agree with submission of the manuscript to your journal.

\section{Competing interests}

The authors declare that they have no competing interests.

\section{Author details}

${ }^{1}$ Microbial Biotechnology and Bioactive Molecules Laboratory: Faculty of Science and Technology Fez, Sidi Mohamed Ben Abdellah University, B.P. 2202-Road of Imouzzer, Fez, Morocco. ${ }^{2}$ AgroBioSciences Mohammed VI Polytechnic University, Lot 660, Hay Moulay Rachid, 43150 Benguerir, Morocco.

Received: 26 May 2020 Accepted: 23 September 2020

Published online: 18 November 2020

\section{References}

1. Es-sbihi FZ, Hazzoumi Z, Benhima R and Joutei KA. Effects of salicylic acid on growth, mineral nutrition, glandular hairs distribution and essential oil composition in Salvia officinalis L. grown under copper stress. Environ Sustain. 2020; 3:199-208

2. Taarit MB, Msaada K, Hosni K, Hammami M, Kchouk ME and Marzouk B. Plant growth, essential oil yield and composition of sage (Salvia officinalis L.) fruits cultivated under salt stress conditions. Indust Crops and Prod. 2009; 30:333-337

3. Özkan M. Glandular and eglandular hairs of Salvia recognita Fisch. and Mey. (Lamiaceae) in Turkey. Bangladesh J Bot. 2008; 37:93-95

4. Werker E, Putievsky E, Ravid U. The essential oils and glandular hairs in different chemotypes of Origanum vulgare L. Ann Bot. 1985;55:793-801.

5. Bisio A, Corallo A, Gastaldo P, Romussi G, Ciarallo G, Fontana N, Profumo P. Glandular Hairs and Secreted Material in Salvia blepharophylla Brandegee ex Epling Grown in Italy. Ann Bot. 1999;83:441-52.
6. Hazzoumi Z, Moustakime Y and Joutei KA Essential Oil and Glandular Hairs: Diversity and Roles. In: Essential Oils-Oils of Nature. IntechOpen; 2019

7. Collins JC, Zinc, in: Lepp, $N$ (Ed.). The Effect of Heavy Metal Pollution on Plants. Applied Science Publishers. London; 1981. p. 145-170

8. Misra A, Srivastava AK, Srivastava NK, Khan A. Zn-acquisition and its role in growth, photosynthesis, photosynthetic pigments, and biochemical changes in essential monoterpene oil (s) of Pelargonium graveolens. Photosynthetica. 2005:43:153-5.

9. Misra A, Sharma S. Zn concentration for essential oil yield and menthol concentration of Japanese mint. Fertilizer Res. 1991;29:261-5.

10. Piccaglia R, Marotti M. Characterization of several aromatic plants grown in northern Italy. Flav Frag J. 1993:8:115-22.

11. Zheljazkov VD, Warman PR. Application of high Cu compost to Swiss chard and basil. J Agric Food Chem. 2003;302:13-26.

12. Chaney RL. Zinc phytotoxicity. In: Zinc in soils and plants. Springer. Dordrecht; 1993. p.135-150

13. Marschner H. Marschner's mineral nutrition of higher plants. Academic press. 2011

14. MacFarlane G.R and Burchett MD. Toxicity, growth and accumulation relationships of copper, lead and zinc in the grey mangrove Avicennia marina (Forsk.) Vierh. Mar Environ Res. 2002; 54: 65-84

15. Macnicol RD, Beckett PHT. Critical tissue concentrations of potentially toxic elements. Plant Soil. 1985;85:107-29.

16. Raskin I, Skubatz H, Tang, Meeuse BJD. Salicylic acid levels in thermogenic and non-thermogenic plants. Annals of Botany. 1990; 66:369-373

17. Popova L, Pancheva T, Uzunova A. Salicylic acid: properties, biosynthesis and physiological role. Bulg J Plant Physiol. 1997;23:85-93.

18. Sakhabutdinova AR, Fatkhutdinova DR, Shakirova FM. Effect of salicylic acid on the activity of antioxidant enzymes in wheat under conditions of salination. Appl Biochem Microbiol. 2004:40:501-5.

19. Fariduddin Q, Hayat S, Ahmad A. Salicylic acid influences net photosynthetic rate, carboxylation efficiency, nitrate reductase activity and seed yield in Brassica juncea. Photosynthetica. 2003;41:281-4.

20. Es-sbihi FZ, Hazzoumi Z, Youssef M, El Hassan, Khalid AJ. Effect of salicylic acid on germination of Ocimum gratissimum seeds induced into dormancy by chlormequat. IJOER. 2016; 150: 2395-6992

21. Klessig DF, Malamy J. The salicylic acid signal in plants Plant. Plant Mol Biol. 1994;26:1439-58.

22. Harper JR, Balke NE. Characterization of the inhibition of $\mathrm{K}^{+}$absorption in oats roots by salicylic acid. Plant Physiol. 1981;68:1349-53.

23. Srivastava MK, Dwivedi UN. Delayed ripening of banana fruit by salicylic acid. Plant sci. 2000;158:87-96.

24. Khan W, Prithviraj B, Smith DL. Photosynthetic responses of corn and soybean to foliar application of salicylates. J Plant Physiol. 2003;160:485-92.

25. Stevens J, Senaratna T, Sivasithamparam K. Salicylic acid induces salinity tolerance in tomato (Lycopersicon esculentum cv. Roma): associated changes in gas exchange, water relations and membrane stabilisation. Plant Growth Regul. 2006; 49:77-83

26. Arfan M, Athar HR, Ashraf M. Does exogenous application of salicylic acid through the rooting medium modulate growth and photosynthetic capacity in two differently adapted spring wheat cultivars under salt stress. J of Plant Physiol. 2007:164:685-94.

27. El-Tayeb MA, El-Enany AE, Ahmad NI. Salicylic acid induces adaptive responses in sunflower (Helianthus annuus L.). Int J Bot. 2006; 2:279-372

28. Kováčik J, Klejdus B, Hedbavny J, Bačkor M. Salicylic acid alleviates NaClinduced changes in the metabolism of Matricaria chamomilla plants. Ecotoxicology. 2009;18:544-54.

29. Popova L, Maslenkova LT, Ivanova A, Stoinova Z. Role of salicylic acid in alleviating heavy metal stress. In: Environmental adaptations and stress tolerance of plants in the era of climate change. Springer. New York, NY; 2012. p. 447-466

30. Mei L, Daud MK, Ullah N, Ali S, Khan M, Malik Z, Zhu SJ. Pretreatment with salicylic acid and ascorbic acid significantly mitigate oxidative stress induced by copper in cotton genotypes. Environ Sci and Pollut Res. 2015;22:9922-31.

31. Tamás L, Mistrík I, Alemayehu A, Zelinová V, Bočová B, Huttová J. Salicylic acid alleviates cadmium-induced stress responses through the inhibition of $\mathrm{Cd}$-induced auxin-mediated reactive oxygen species production in barley root tips. J of plant physiol. 2015;173:1-8. 
32. Mckinney G. Absorption of light by chlorophyll solutions. J Biol Chem. 1941;140:315-32.

33. Cottenie A, Verloo M, Kiekens L, Velghe G, Camerlynck R. Chemical Analysis of Plant and Soil laboratory of analytical and Agrochemistry. Belgium: State University Ghent; 1982. p. 100-129.

34. Copetta A, Lingua $G$ and Berta G. Effects of three AM fungi on growth, distribution of glandular hairs, and essential oil production in Ocimum basilicum L. var. Genovese. Mycorrhiza. 2006;16: 485-494

35. Hazzoumi Z, Moustakime Y, Joutei KA. Effect of arbuscular mycorrhizal fungi and water stress on ultrastructural change of glandular hairs and essential oil compositions in Ocimum gratissimum. Chem Biol Technol in Agric. 2017;4:20.

36. Sresty TVS, Madhava Rao KV. Les modifications ultrastructurales en réponse à un stress zinc et de nickel dans les cellules de la racine de pois de pigeon. Environ Exp Bot. 1999;41:3-13.

37. Sagardoy R, Morales F, López-Millán AF, Abadía A, Abadía J. Effects of zinc toxicity on sugar beet (Beta vulgaris L.) plants grown in hydroponics. Plant Biol. 2009;11:339-350

38. Frey B, Keller C, Zierold K, Schulin R. Distribution of Zn in functionally different leaf epidermal cells of the hyperaccumulator Thlaspica erulescens. Plant, Cell and Environ. 2000;23:675-87.

39. Turner RG, Marshall C. The accumulation of zinc by subcellular fractions of roots of Agrostis tenuis Sibth. relation to zinc tolerance, New Phytol. 1972:71:671-6.

40. Chaudhry FM, Alam SM, Rashid A, Latif A. Mechanism of differential susceptibility of two rice varieties to Zn deficiency. Plant Soil. 1995:46:637-42

41. El-Metwally AE, Abdalla FE, El-Saady AM, Safina SA, El-Sawy SS. Response of wheat to magnesium and copper foliar feeding under sandy soil condition. J Am Sci. 2010; 6:818-823

42. Adrees M, Ali S, Rizwan M, Ibrahim M, Abbas F, Farid M, Bharwana S. The effect of excess copper on growth and physiology of important food crops: a review. Environ Sci Pollut Res. 2015;22:8148-62.

43. Sandalio LM, Rodrı'guez-Serrano M, Del-RI'o LA, Romero-Puertas MC. Reactive oxygen species and signaling in cadmium toxicity. In: del Rio LA Puppo A (eds) Reactive oxygen species in plant. Springer. Berlin; 2009. p. 175-189

44. Ambler JE, Brown JC, Gauch HG. Effect of zinc on translocation of iron in soybean plants. Plant Physiol. 1970;46:320-32.

45. Hashmi N, Khan MMA, Idrees M, Aftab T. Exogenous salicylic acid stimulates physiological and biochemical changes to improve growth, yield and active constituents of fennel essential oil. Plant growth regul. 2012;68:281-91.

46. Croteau R. Biosynthesis and catabolism of monoterpenoids. Chem Rev. 1987;87:929-54

47. Díaz J, Bernal A, Pomar F, Merino F. Induction of shikimate dehydrogenase and peroxidase in pepper (Capsicum annuum L.) seedlings in response to copper stress and its relation to lignification. Plant Sci. 2001; 161:179-188

48. Prakasa REV, Ganesha RRS, Ramesh S. Seasonal variation in oil content and its composition in two chemotypes of scented geranium (Pelargonium sp.). J of Essen Oil Res. 1995; 7:159-163

49. Corsi G, Bottega S. Glandular hairs of Salvia officinalis: new data on morphology, localization and histochemistry in relation to function. Ann Bot. 1999;84:657-64

50. Serrato-Valenti G, Bisio A, Cornara L, Ciarallo G. Structural and histochemical investigation of the glandular trichomes of Salvia aurea L. leaves, and chemical analysis of the essential oil. Ann Bot. 1997; 79:329-36

51. Janošević D, Budimir S, Alimpić A, Marin P, Al Sheef N, Giweli A, DuletićLaušević S. Micromorphology and histochemistry of leaf trichomes of Salvia aegyptiaca (Lamiaceae). Arch Biol Sci. 2016;68:291-301.

52. Makandar R, Essig JS, Schapaugh MA, Trick HN, Shah J. Genetically engineered resistance to Fusarium head blight in wheat by expression of Arabidopsis NPR1. Mol Plant Microbe Intearact. 2006;19:123-9.

53. Hayat $Q$, Hayat $S$, Irfan M, Ahmad A. Effect of exogenous salicylic acid under changing environment: a review. Environ and experm botany. 2010;68:14-25.

54. Es-sbihi FZ, Hazzoumi Z, Youssef M, Hassan E, Khalid AJ. Effect of salicylic acid and salt stress on the growth and some biochemical parameters of Mentha suaveolens. Int J Sci Eng Res. 2016;7:54-62.

55. Rouphael Y, Raimondi G, Lucini L, Carillo P, Kyriacou MC, Colla G, Cirillo V, Pannico A, El-Nakhel C, Pascale SD. Physiological and metabolic responses triggered by omeprazole improve tomato plant tolerance to $\mathrm{NaCl}$ stress. Front Plant Sci. 2018;9:249.

56. Damalas CA. Improving drought tolerance in sweet basil (Ocimum basilicum) with salicylic acid. Sci Hort. 2019;246:360-5

57. Jahan MS, Wang Y, Shu S, Zhong M, Chen Z, Wu J, Guo S. Exogenous salicylic acid increases the heat tolerance in tomato (Solanum lycopersicum L) by enhancing photosynthesis efficiency and improving antioxidant defense system through scavenging of reactive oxygen species. Sci Hortic. 2019:247:421-9.

58. Szalai G, Krantev A, Yordanova R, Popova LP, Janda T. Influence of salicylic acid on phytochelatin synthesis in Zea mays during Cd stress. Turk J Bot. 2013:37:708-14.

59. Shakirova FM, Sakhabutdinova AR, Bezrukova MV, Fatkhutdinova RA, Fatkhutdinova DR. Changes in the hormonal status of wheat seedlings induced by salicylic acid and salinity. Plant sci. 2003;164:317-22.

60. Wilkinson S, Davies WJ. Drought, ozone, ABA and ethylene: new insights from cell to plant to community. Plant, Cell and Environ. 2010;33:510-25.

61. Bari $\mathrm{R}$, Jones JD. Role of plant hormones in plant defense responses. Plant Mol Biol. 2009;69:473-88.

62. Shakirova FM, Bezrukova MV, Maslennikova DR. Endogenous ABA as a hormonal intermediate in the salicylic acid induced protection of wheat plants against toxic ions. In: Salicylic Acid. Springer. Dordrecht; 2013. p. 119-140

63. Guo Q, Meng L, Maoa P, Jia Y, Shi Y. Role of exogenous salicylic acid in alleviating cadmium induced toxicity in Kentucky bluegrass. Biochem Syst Ecol. 2013;50:269-76

64. Gunes A, Inal A, Alpaslan M, Cicek N, Guneri E, Eraslan F, Guzelordu T. Effects of exogenously applied salicylic acid on the induction of multiple stress tolerance and mineral nutrition in maize (Zea mays L.). Arch of Agron and Soil Sci. 2005; 51:687-695

65. Tahjib UM, Siddiqui MN, Sohag AAM, Sakil MA, Rahman MM, Polash M, Tran L. Salicylic acid-mediated enhancement of photosynthesis attributes and antioxidant capacity contributes to yield improvement of maize plants under salt stress. J of plant growth regul. 2018;37:1318-30.

66. Faghih S, Ghobadi C, Zarei A Response of strawberry plant CV. 'Camarosa' to salicylic acid and methyl jasmonate application under salt stress condition. J Plant Growth Regul; 2017 36:651-659

67. Mateo A, Funck D, Mu-hlenbock P, Kular B, Mullineaux PM and Karpinski S. Controlled levels of salicylic acid are required for optimal photosynthesis and redox homeostasis. J Exp Bot. 2006; 57:1795-1807

68. Khan IR, Asgher M, Khan NA. Alleviation of salt-induced photosynthesis and growth inhibition by salicylic acid involves glycinebetaine and ethylene in mungbean (Vigna radiata L.). Plant Physiol and Bioch. 2014; 80:67-74.

69. Shi Q, Bao Z, Zhu Z, Ying Q, Qian Q. Effects of different treatments of salicylic acid on heat tolerance, chlorophyll fluorescence, and antioxidant enzyme activity in seedlings of Cucumis sativa L. Plant Growth Regul. 2006:48:127-35.

70. Khanam D, Mohammad F. Plant growth regulators ameliorate the ill effect of salt stress through improved growth, photosynthesis, antioxidant system, yield and quality attributes in Mentha piperita L. Acta Physiol Plant. 2018;40:188.

71. Idrees M, Khan MMA, Aftab T, Naeem M and Hashmi N. Salicylic acidinduced physiological and biochemical changes in lemongrass varieties under water stress. J of Plant Intera5:293-303

72. Rowshan $V$, Khoi MK, Javidnia K. Effects of salicylic acid on quality and quantity of essential oil components in Salvia macrosiphon. J Biol Environ Sci. 2010;20104:77-82.

73. Tomaszewski M, Thimann KV. Interactions of phenolic acids, metallic ions and chelating agents on auxin-induced growth. Plant Physiol. 1966;41:1443-544.

\section{Publisher's Note}

Springer Nature remains neutral with regard to jurisdictional claims in published maps and institutional affiliations. 